\title{
Hiring Editorial Member for Receiving Papers from Authors
}

\author{
Mehdi Dadkhah* \\ Ali Tarhini² \\ Vyacheslav V. Lyashenko 3 \\ Mohammad Davarpanah Jazi ${ }^{1}$ \\ ${ }^{1}$ Department of Computer and Information Technology, Foulad Institute of Technology, Foulad shahr, Isfahan 8491663763, Iran \\ 2Department of Information Systems, Brunel University London, Uxbridge, Middlesex, United Kingdom \\ ${ }^{3}$ The chief of the laboratory "Transfer of Information Technologies in the Risk Reduction Systems", Faculty of Applied \\ Mathematics and Management, Department of Informatics, Kharkov National University of Radio Electronics, Ukraine \\ Correspondence Email: dadkhah80@gmail.com, mdt@dr.com
}

\section{Doi:10.5901/mjss.2015.v6n4p11}

The academic world encountered many challenges and unethical issues that were discussed by us and other researchers, such as hijacked journals (Jalalian \& Mahboobi, 2014; Jalalian, 2014; Dadkhah et al, 2015), bogus impact factor (Jalalian \& Mahboobi, 2013), fake conferences (Dadkhah, Jazi, Pacukaj, 2015), social engineering (Dadkhah \& Quliyeva, 2014) and predatory publishers (Tin et al, 2014). For instance, it is worth nowadays to highlight the rise of a new kind of unethical concern that is increasingly growing between some predatory low level journals. The problem faced by these journals lies in the fact that they lack the existence of papers to be published in their issues and therefore they resorted to the solution of hiring editorial board for encouraging authors to send their researching work to their respective journals. In other terms, the strategy of that kind of journals is to invite well-known and popular practitioners in some fields to hire them as editorial members for receiving papers from authors all around the world. More specifically, some of these journals impose on their editorial members to send them their papers for publication at the condition of being removed from the editorial members list if they don't approve their requests. Other cases of these unethical issues could have the scenario where the editor resorts to the fact of targeting people lacking well-established academic experience and do them a favor by hiring them as editorial members and eventually they will be happy to follow the orders of administration by simply encouraging other authors to submit their work to their journals so that they can secure the positions offered to them. Nowadays this technique is widely adopted nowadays by hijacked journals.

Unfortunately, a lot of researchers have no idea about the existence of such journals and they either keep sending requests asking to be hired as one of the editorial members or will directly accept requests and call invitations for editorial hiring as well as encouraging their colleagues to submit their researching studies to these journals.

Another case widely used recently by theses hijackers is to call for editorial hiring people with distinguished academic achievements and ranks such as head of departments and popular lecturers of well-known universities. They try their best to hire them so that, students of these popular people will eventually submit their papers in these hijacked journals. For instance, we can name MAGNT Research Report (http://brisjast.com) and Waliaj (http://www.waliaj.com) as being ones of the more powerful hijacked journals that have used this technique to receive papers. MAGNT Research Report (hijacked version) has 47 editorial members and Waliaj has 45 editorial members. Table 2 shows difference between calls for editor in trusted and hijacked journals' call.

Table 1. Difference between a call for editor in trusted and hijacked journals' call.

\begin{tabular}{|c|c|c|c|c|c|}
\hline & Email Format & CV Evaluation Time & Sender of E-mail Address & Reason of Invitation & Indexing \\
\hline Trusted Journals & $\begin{array}{c}\text { Email with attached } \\
\text { pdf invitation }\end{array}$ & About a month or more & $\begin{array}{c}\text { Official email address from } \\
\text { editor }\end{array}$ & $\begin{array}{l}\text { Hiring expert people in } \\
\text { fields }\end{array}$ & $\begin{array}{c}\text { Scopus, } \\
\text { Thomson Reuter }\end{array}$ \\
\hline $\begin{array}{l}\text { Low Level Journals or } \\
\text { Hijacked Journals }\end{array}$ & Simple email & $\begin{array}{l}\text { There are no evolution } \\
\text { or simple evaluation. }\end{array}$ & General mail services & For publicity of journal & $\begin{array}{l}\text { Not credible } \\
\text { indexing }\end{array}$ \\
\hline
\end{tabular}

We highly recommend to inspect the quality and credibility of journals before applying for editorial board. This is very 
important because you may end up applying for hijacked journals that heavily rely on social engineering techniques to be able to easily cheat researchers.

\section{References}

Dadkhah M, Jazi M.D, Pacukaj S. (2015). Fake Conferences for Earning Real Money. Mediterranean Journal of Social Sciences. Vol. 6 , No. 2, 11-12. DOI:10.5901/mjss.2015.v6n2p11

Dadkhah M, Obeidat MM, Jazi MD, Sutikno T, Riyadi MA. (2015). How Can We Identify Hijacked Journals?. Bulletin of Electrical Engineering and Informatics. Vol. 4, No. 2, 83-87. DOI: 10.12928/eei.v4i2.449.

Dadkhah M, Quliyeva A. (2014). Social Engineering in Academic World. Journal of Contemporary Applied Mathematics. Vol. 4, No. 2, 35.

Jalalian M, Mahboobi H. (2014). Hijacked Journals and Predatory Publishers: Is There a Need to Re-Think How to Assess the Quality of Academic Research?. Walailak J Sci \& Tech, Vol. 11, No. 5, 389-394.

Jalalian M. (2014). Hijacked Journals Are Attacking the Reliability and Validity of Medical Research. Electronic Physician. Vol. 6, No. 4, 925-926. DOI: 10.14661/2014.925-926.

Jalalian M, Mahboob H. (2013). New Corruption Detected: Bogus Impact Factors Compiled By Fake Organizations. Electronic physician. Vol. 5, No. 3, 685-686. DOl: 10.14661/2013.685-686.

Tin A, Ivana B, Biljana B, Ljubica I. B, Dragan M, Dušan. (2014). Predatory and Fake Scientifi Journals/Publishers - A Global Outbreak with Rising Trend: A Review. Geographica Pannonica. Vol. 18, No. 3, 69-81. 